\title{
Urban Growth of Palembang and Its Impact on Land Surface Temperature Using Remote Sensing and GIS Technique
}

\author{
Johannes Adiyanto ${ }^{1}$, Adhika Atyanta ${ }^{2}$ \\ \{johannesadiyanto@ft.unsri.ac.id ${ }^{1}$, adhika.atyanta@gmail.com ${ }^{2}$ \} \\ Universitas Sriwijaya, Jl. Palembang - Prabumulih KM.32 Kabupaten Ogan Ilir, \\ South Sumatera, Indonesia ${ }^{1,2}$
}

\begin{abstract}
Palembang has a new identity after a sports event. Palembang transforms from river city to landed city. This research analyses the transformation of Palembang using remote sensing and spatial metrics. This research used 3 different images of the map take from Landsat image. That maps separates into 4 categories: first maps from 2001 and 2003, before National sports event in 2004; second map, after SEA Games, map 2014; the third from the maps of 2015 and 2016 (before Asian Games 2018) and the last map at 2018, after all sport event at Palembang. Those maps are taken from Landsat 7 dataset and were analysed into two different categories, first categories were analysed the built-up index and second one about land surface temperature. This research shows that sports events can transform Palembang into a modern city. The result shows that the urban growth of Palembang brought the impact that the land surface temperature increased.
\end{abstract}

Keywords: Urban Growth, Remote Sensing Analysis, GIS Technique, and Land Surface Temperature

\section{Introduction}

Palembang is one of the oldest city in Indonesia. In past time, Palembang develops based on Musi river. There were many important places in kingdom era or old kampong located at Musi riverbank. This situation also happened when many oil companies build their refinery and dwelling area. Musi river becomes an important infrastructure in that time(Sevenhoven, 2015).

The urban growth of Palembang was spurred on urban transportation. It was occurred when the Dutch build their dwelling place at Talang Semut. That located little bit far from Musi riverbank. The Dutch government also build many roads in Palembang. Talang Semut become the first 'real estate' in Palembang and the first urban sprawl area. After that, Japanese also build a road from core old city to the airport, around $15 \mathrm{~km}$. In 1962, Palembang has a big bridge to connect between North area (Ilir side) to South area (Ulu Side). That is Ampera Bridge, and today become an icon of Palembang(Santun, 2011). Right now, the road become 'backbone' of infrastructure in Palembang.

This research tries to show that information from remote sensing data can be basic information to plan the city in the future, like Batty describe how the growth of big data is shifting the emphasis from longer-term strategic planning to short-term thinking about how cities function and can be managed, although with the possibility that over much longer periods of time, this kind of big data will become a source for information about every time horizon (Batty, 2013). 
This paper is the first steps of collecting data for complete big data of Palembang city. This paper show identifies the urban growth of Palembang. This identified the second phase of that transformation of Palembang city. Now, Palembang known as a sports city, because at the South area (Ulu side) already build a sports facility. That facilities build before PON XVI at 2004, called Jakabaring Sports city. The paper identifying urban growth at 2001 and 2003, before a national sports event, the second period after SEA GAMES, at 2014, the third period at 2015 and 2016, after before Asian Games and the fourth period at 2018. This result of identified is how the trend of urban growth of Palembang and how large urban sprawl in this city. This identification result can be interpreted how the infrastructure in Palembang support city growth.

The research using remote sensing data analysis for measuring the built-up area was already done in Yogyakarta (Hidayati, Suharyadi, \& Danoedoro, 2018). The Improving the normalized difference built-up index to map urban built-up area also was already done by research team from Beijing Normal University (He, Shi, Xie, \& Zhao, 2010). The research which have aim to count the air temperature using remote sensing data analysis already did in Beijing (Zhang \& $\mathrm{Du}, 2019)$. This research try to get the connection between built-up area and UHI.

The main question of this paper, the first steps of research, is how is Palembang growth? And what is the environment impact? The main purpose of this paper is making critics of urban planning of Palembang. This paper explores the potential problem which can happen in the future time.

\section{Method}

This paper used remote sensing data analysis for main method. The data sources used Landsat 7 dataset $^{1}$. Generally, Landsat data are used for classification. Landsat data having several bands based on their wavelength (blue band, green band, red band, infrared band, thermal band, panchromatic). Panchromatic band is used for increase the resolution of data. Landsat 7 data having total of 8 band while Landsat 8 data having 11 bands $^{2}$. This is the detail of Landsat 7 dataset:

Table 1. Landsat Dataset and datetime

\begin{tabular}{ccccc}
\hline No & Satellite & \multicolumn{1}{c}{ ID } & Date time \\
\hline $\mathbf{1}$ & Landsat 7 & LE07_L1TP_124062_20010713_20170204_01_T1 & 3-Jul-01 \\
\hline $\mathbf{2}$ & Landsat 7 & LE07_L1TP_124062_20031023_20170124_01_T1 & 23-Oct-03 \\
\hline $\mathbf{3}$ & Landsat 7 & LE07_L1TP_124062_20071002_20170101_01_T1 & 2-Oct-07 \\
\hline $\mathbf{4}$ & Landsat 7 & LE07_L1TP_124062_20120913_20161129_01_T1 & 13-Sep-12 \\
\hline $\mathbf{5}$ & Landsat 7 & LE07_L1TP_124062_20140802_20161111_01_T1 & 2-Aug-14 \\
\hline $\mathbf{6}$ & Landsat 7 & LE07_L1TP_124062_20150704_20161024_01_T1 & 4-Jul-15 \\
\hline $\mathbf{7}$ & Landsat 7 & LE07_L1TP_124062_20160807_20161009_01_T1 & 7-Aug-16 \\
\hline $\mathbf{8}$ & Landsat 7 & LE07_L1TP_124062_20181117_20181214_01_T1 & 17-Nov-18 \\
\hline
\end{tabular}

In build-up index side (right side of Fig 1.), this paper used work of Tek Bahadur Kshestri ${ }^{3}$ friends worked. They explained that land Surface Temperature (LST) is the temperature of the

\footnotetext{
${ }^{1}$ https://landsat.gsfc.nasa.gov/landsat-7/

${ }^{2}$ https://www.linkedin.com/pulse/ndvi-ndbi-ndwi-calculation-using-landsat-7-8-tek-bahadurkshetri.

${ }^{3}$ Source: https://np.linkedin.com/in/iamtekson?trk=author_mini-profile_image and published at https://www.linkedin.com/pulse/ndvi-ndbi-ndwi-calculation-using-landsat-7-8-tek-bahadur-kshetri
} 
surface which can be measured when the land surface is in direct contact to the measuring instrument(Jeevalakshmi, Narayana Reddy, \& Manikiam, 2017).

Based on that dataset, this paper used this steps:

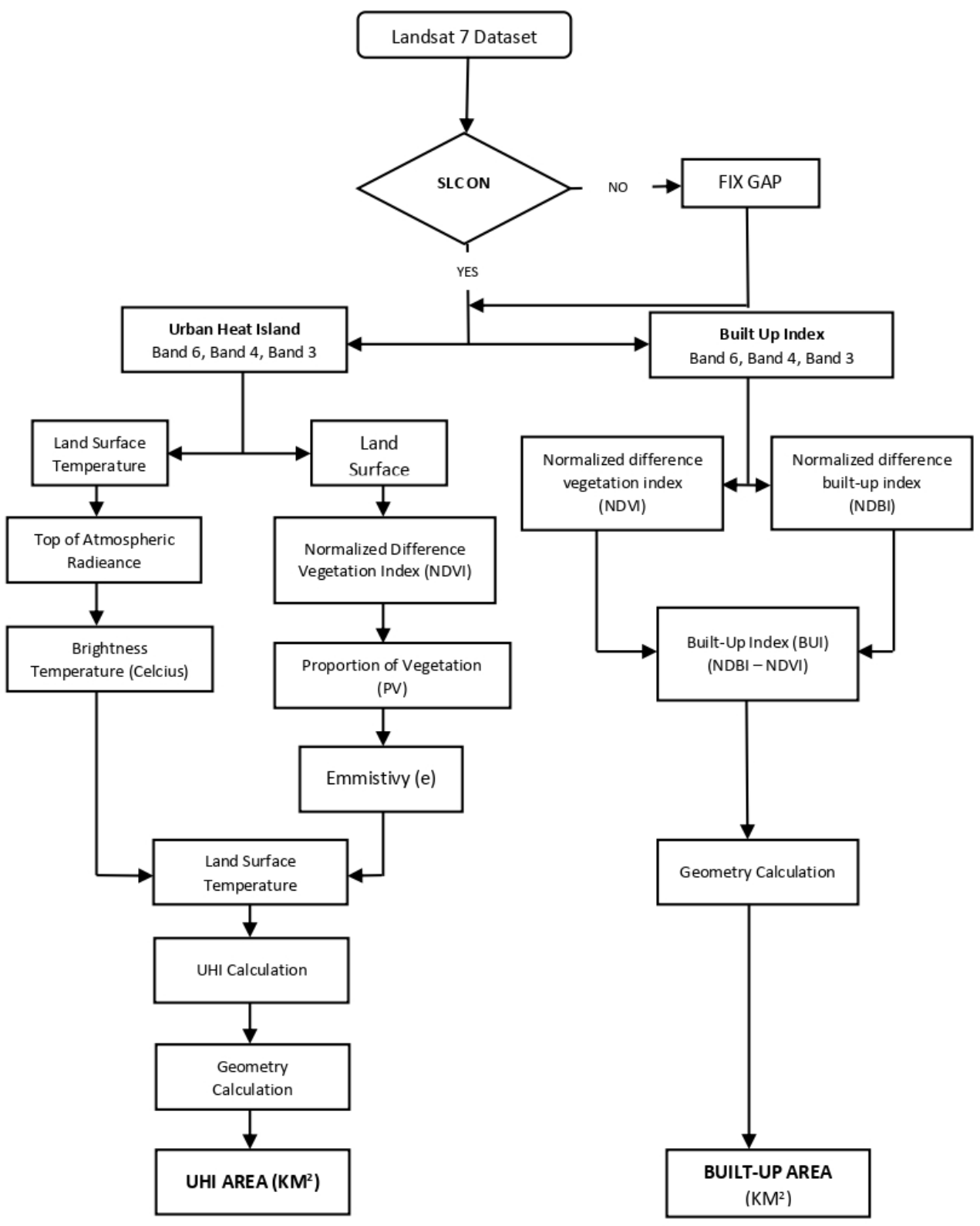

Fig. 1. Flowchart of analysis technique 


\section{Results And Discussions \\ 3.1. Validation explanation}

In table 1 this paper used dataset from 2001, 2003, 2007, 2012, 2014, 2015, 2016 and 2018.

This result have to validation. This was the colleration:

Table 2. Correlation All dataset

\begin{tabular}{|c|c|c|c|c|c|c|c|c|c|c|}
\hline \multicolumn{11}{|c|}{ Correlations } \\
\hline & & VAR2001 & VAR2003 & VAR2007 & VAR2012 & VAR2014 & VAR2015 & VAR2016 & VAR2018 & VARTOTAL \\
\hline \multirow[t]{3}{*}{ VAR2001 } & Pearson Correlation & 1 & $.999^{\prime \prime}$ & .709 & .699 & $.984^{\circ}$ & $.990^{\prime \prime}$ & $.971^{\circ}$ & $.952^{\circ}$ & $.969^{\circ}$ \\
\hline & Sig. (2-tailed) & & .001 & .291 & .301 & .016 & .010 & .029 & .048 & .031 \\
\hline & $\mathrm{N}$ & 4 & 4 & 4 & 4 & 4 & 4 & 4 & 4 & 4 \\
\hline \multirow[t]{3}{*}{ VAR2003 } & Pearson Correlation & $.999 "$ & 1 & .733 & .724 & $.990^{\circ}$ & $.995^{\prime \prime \prime}$ & $.979^{\circ}$ & $.962^{*}$ & $.977^{n}$ \\
\hline & Sig. (2-tailed) & .001 & & .267 & .276 & .010 & .005 & .021 & .038 & .023 \\
\hline & $\mathrm{N}$ & 4 & 4 & 4 & 4 & 4 & 4 & 4 & 4 & 4 \\
\hline \multirow[t]{3}{*}{ VAR2007 } & Pearson Correlation & .709 & .733 & 1 & $1.000^{\mathrm{m}}$ & .823 & .800 & .858 & .891 & .861 \\
\hline & Sig. (2-tailed) & .291 & .267 & & .000 & .177 & .200 & .142 & .109 & .139 \\
\hline & $\mathrm{N}$ & 4 & 4 & 4 & 4 & 4 & 4 & 4 & 4 & 4 \\
\hline \multirow[t]{3}{*}{ VAR2012 } & Pearson Correlation & .699 & .724 & $1.000^{\mathrm{m}}$ & 1 & .815 & .792 & .850 & .884 & .854 \\
\hline & Sig. (2-tailed) & .301 & .276 & .000 & & .185 & .208 & .150 & .116 & .146 \\
\hline & $\mathrm{N}$ & 4 & 4 & 4 & 4 & 4 & 4 & 4 & 4 & 4 \\
\hline \multirow[t]{3}{*}{ VAR2014 } & Pearson Correlation & $.984^{\circ}$ & $.990^{\circ}$ & .823 & .815 & 1 & $.999^{\prime \prime}$ & $.998^{\prime \prime}$ & $.991^{\prime \prime}$ & $.998^{\prime \prime}$ \\
\hline & Sig. (2-tailed) & .016 & .010 & .177 & 185 & & .001 & .002 & .009 & .002 \\
\hline & $\mathrm{N}$ & 4 & 4 & 4 & 4 & 4 & 4 & 4 & 4 & 4 \\
\hline \multirow[t]{3}{*}{ VAR2015 } & Pearson Correlation & $.990^{\circ "}$ & $.9955^{\prime \prime}$ & .800 & .792 & $.999 "$ & 1 & $.995^{\prime \prime}$ & $.985^{\prime \prime}$ & $.994^{\prime \prime \prime}$ \\
\hline & Sig. (2-tailed) & .010 & .005 & .200 & .208 & .001 & & .005 & .015 & .006 \\
\hline & $\mathrm{N}$ & 4 & 4 & 4 & 4 & 4 & 4 & 4 & 4 & 4 \\
\hline \multirow[t]{3}{*}{ VAR2016 } & Pearson Correlation & $.971^{\prime \prime}$ & $.979^{\circ}$ & .858 & .850 & $.998^{\prime \prime \prime}$ & $.995^{\prime \prime}$ & 1 & $.998^{\prime \prime \prime}$ & $1.000^{\mathrm{m}}$ \\
\hline & Sig. (2-tailed) & .029 & .021 & .142 & 150 & .002 & .005 & & .002 & .000 \\
\hline & $\mathrm{N}$ & 4 & 4 & 4 & 4 & 4 & 4 & 4 & 4 & 4 \\
\hline \multirow[t]{3}{*}{ VAR2018 } & Pearson Correlation & $.952^{\circ}$ & $.962^{\circ}$ & .891 & .884 & $.991^{\prime \prime}$ & $.985^{\circ}$ & $.998^{\prime \prime}$ & 1 & $.998^{\prime \prime \prime}$ \\
\hline & Sig. (2-tailed) & .048 & .038 & .109 & . 116 & .009 & .015 & .002 & & .002 \\
\hline & $\mathrm{N}$ & 4 & 4 & 4 & 4 & 4 & 4 & 4 & 4 & 4 \\
\hline \multirow[t]{3}{*}{ VARTOTAL } & Pearson Correlation & $.969^{\circ}$ & $.977^{\circ}$ & .861 & .854 & $.998^{\prime \prime}$ & $.994^{\prime \prime}$ & $1.000^{\prime \prime \prime}$ & $.998^{\prime \prime}$ & 1 \\
\hline & Sig. (2-tailed) & .031 & .023 & .139 & .146 & .002 & .006 & .000 & .002 & \\
\hline & $\mathrm{N}$ & 4 & 4 & 4 & 4 & 4 & 4 & 4 & 4 & 4 \\
\hline
\end{tabular}

$*$ Correlation is significant at the 0.01 level (2-tailed).

*. Correlation is significant at the 0.05 level (2-tailed).

Table 2 showed that in 2007 and 2012 was not valid data, because Var2007 has Pearson nya $0.86 x$, sig. 0.139 and Var2012 has Pearson $0.85 x$, sig 0.146 . Valid data has sig $>0.05$ and Pearson $>0.95$. This was an argument why dataset in 2007 and 2012 be taken out from dataset. 
After invalid data has been issued, this was the correlation:

Table 3. Correlation valid dataset

\begin{tabular}{|c|c|c|c|c|c|c|c|c|}
\hline \multicolumn{9}{|c|}{ Correlations } \\
\hline & & v2001 & v2003 & V2014 & v2015 & v2016 & v2018 & total \\
\hline \multirow[t]{3}{*}{ v2001 } & Pearson Correlation & 1 & $.999^{* "}$ & $.984^{*}$ & $.990^{\mathrm{N*}}$ & $.971^{*}$ & $.952^{*}$ & $.991^{* \prime}$ \\
\hline & Sig. (2-tailed) & & .001 & .016 & .010 & .029 & .048 & .009 \\
\hline & $\mathrm{N}$ & 4 & 4 & 4 & 4 & 4 & 4 & 4 \\
\hline \multirow[t]{3}{*}{ v2003 } & Pearson Correlation & $.999^{* \pi}$ & 1 & $.990^{\circ}$ & $.995^{* *}$ & $.979^{*}$ & $.962^{*}$ & $.995^{\mathrm{N*}}$ \\
\hline & Sig. (2-tailed) & .001 & & .010 & .005 & .021 & .038 & .005 \\
\hline & $\mathrm{N}$ & 4 & 4 & 4 & 4 & 4 & 4 & 4 \\
\hline \multirow[t]{3}{*}{ v2014 } & Pearson Correlation & $.984^{*}$ & $.990^{\circ}$ & 1 & $.999^{* "}$ & $.998^{* *}$ & $.991^{* *}$ & $.999^{* \prime}$ \\
\hline & Sig. (2-tailed) & .016 & .010 & & .001 & .002 & .009 & .001 \\
\hline & $\mathrm{N}$ & 4 & 4 & 4 & 4 & 4 & 4 & 4 \\
\hline \multirow[t]{3}{*}{ v2015 } & Pearson Correlation & $.990^{* *}$ & $.995^{* *}$ & $.999^{* "}$ & 1 & $.995^{* *}$ & $.985^{*}$ & $1.000 "$ \\
\hline & Sig. (2-tailed) & .010 & .005 & .001 & & .005 & .015 & .000 \\
\hline & $\mathrm{N}$ & 4 & 4 & 4 & 4 & 4 & 4 & 4 \\
\hline \multirow[t]{3}{*}{ v2016 } & Pearson Correlation & $.971^{*}$ & $.979^{*}$ & $.998^{* *}$ & $.995^{* *}$ & 1 & $.998^{* *}$ & $.994^{* *}$ \\
\hline & Sig. (2-tailed) & .029 & .021 & .002 & .005 & & .002 & .006 \\
\hline & $\mathrm{N}$ & 4 & 4 & 4 & 4 & 4 & 4 & 4 \\
\hline \multirow[t]{3}{*}{ v2018 } & Pearson Correlation & $.952^{*}$ & $.962^{*}$ & $.991^{\prime *}$ & $.985^{*}$ & $.998^{* *}$ & 1 & $.984^{*}$ \\
\hline & Sig. (2-tailed) & .048 & .038 & .009 & .015 & .002 & & .016 \\
\hline & $\mathrm{N}$ & 4 & 4 & 4 & 4 & 4 & 4 & 4 \\
\hline \multirow[t]{3}{*}{ total } & Pearson Correlation & $.991^{* *}$ & $.995^{* *}$ & $.999^{* *}$ & $1.000^{* *}$ & $.994^{* *}$ & $.984^{*}$ & 1 \\
\hline & Sig. (2-tailed) & .009 & .005 & .001 & .000 & .006 & .016 & \\
\hline & $\mathrm{N}$ & 4 & 4 & 4 & 4 & 4 & 4 & 4 \\
\hline
\end{tabular}

**. Correlation is significant at the 0.01 level (2-tailed)

*. Correlation is significant at the 0.05 level (2-tailed).

If both dataset was compared with Cronbach's alpha, we could see the result below:

Table 4. Reliability Statistic

\begin{tabular}{cccc}
\hline & Reliability Statistics & Table \\
\cline { 2 - 4 } & $\begin{array}{c}\text { Cronbach's } \\
\text { Alpha }\end{array}$ & $\begin{array}{c}\text { Cronbach's Alpha Based on } \\
\text { Standardized Items }\end{array}$ & $\begin{array}{c}\text { N of } \\
\text { Items }\end{array}$ \\
\hline $\begin{array}{c}\text { Table 2 Correlation All } \\
\text { dataset }\end{array}$ & $\mathbf{. 9 8 0}$ & .987 & 8 \\
\hline $\begin{array}{c}\text { Table 3 Correlation valid } \\
\text { dataset }\end{array}$ & $\mathbf{9 9 0}$ & .998 & 6 \\
\hline
\end{tabular}




\subsection{Built Up Area}

Built-up Index which used NDBI and NDVI following this formulation: NDBI - NDVI $=$ BU. The result of Built-up directly to change to kilometre square area. The result of analysis can describe like this:

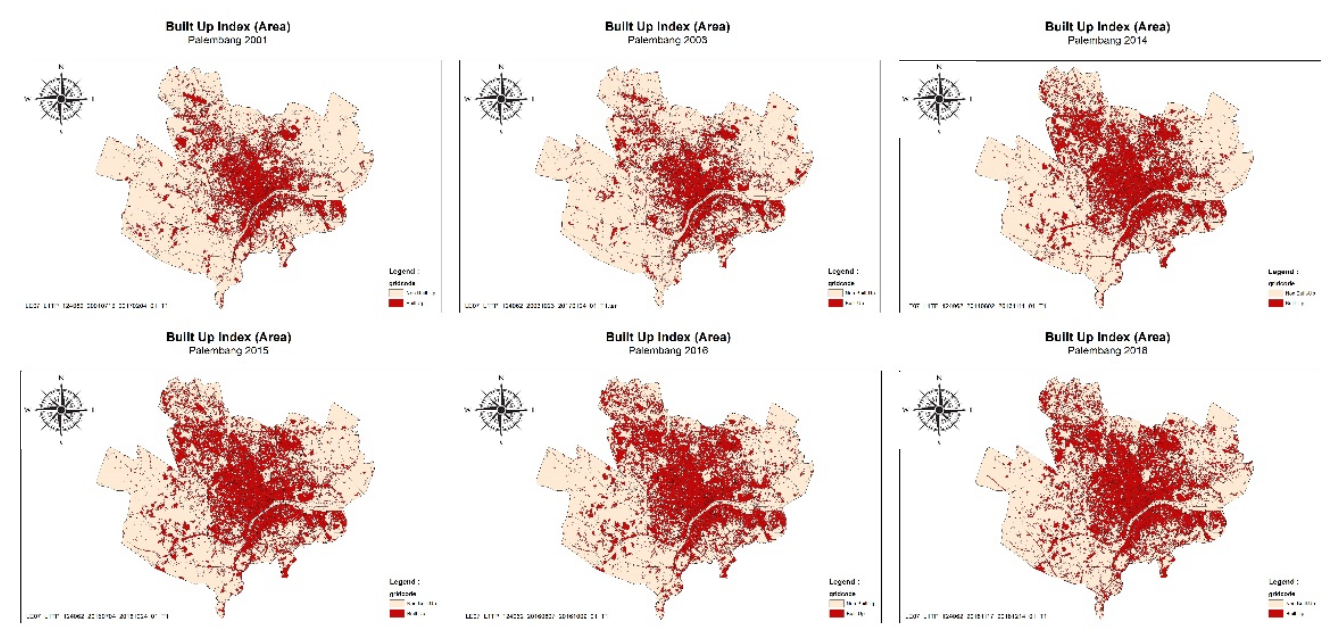

Fig. 2. Built up Index of Palembang in $\mathrm{KM}^{2}$

Based on result, the built area can describe like this table:

Table 5. Built-up Area in $\mathrm{km}^{2}$

\begin{tabular}{ccccccc}
\hline & \multicolumn{7}{c}{ Built-Up Area $(\mathbf{K m 2})$} \\
\hline Years & 2001 & 2003 & 2014 & 2015 & 2016 & 2018 \\
\hline Non BU & 278 & 276 & 246 & 238 & 233 & 225 \\
\hline BU & 89 & 91 & 121 & 129 & 134 & 142 \\
\hline TOTAL & 367 & 367 & 367 & 367 & 367 & 367 \\
\hline
\end{tabular}

Table 5 showed that at 2014 there was an increase in built-up area. For detail, we can see below:

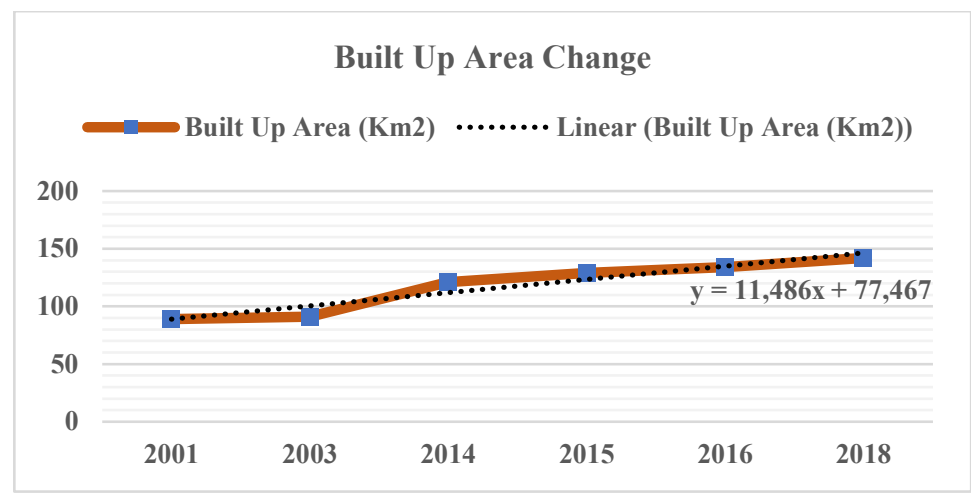

Fig. 3. Growth Chart of Built-up Area 


\subsection{Land Surface Temperature.}

The result of Land Surface Temperature (LST) can be visualized in this figure:
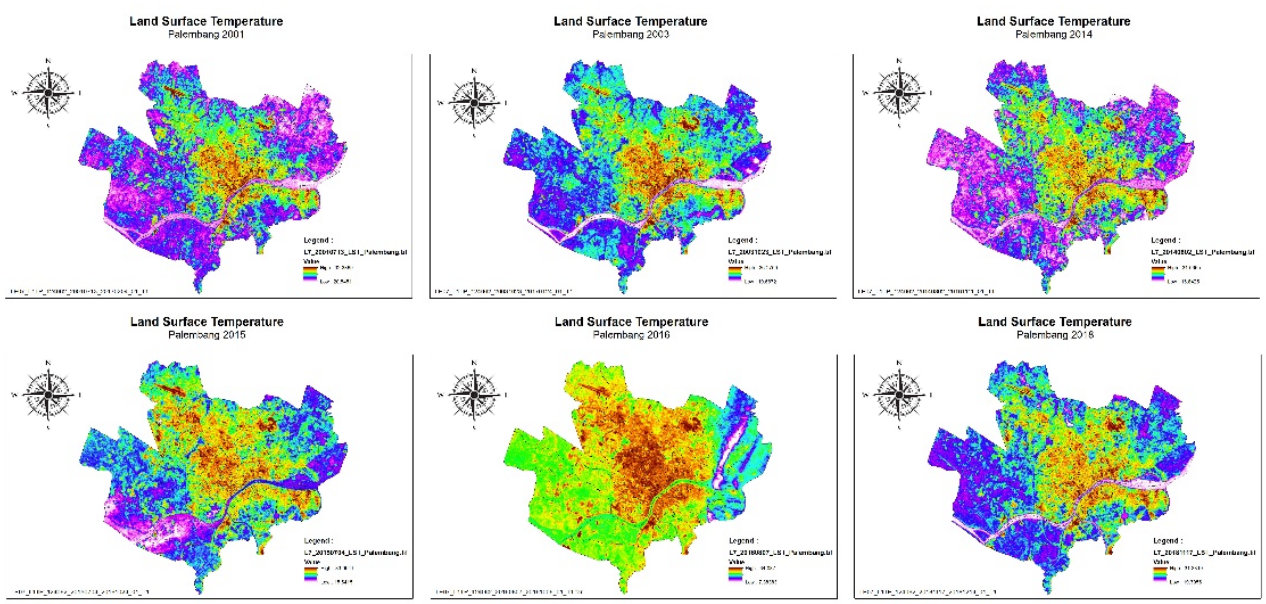

Fig. 4. LST of Palembang

A UHI is recognized as a climatic phenomenon in which urban areas have higher air temperature than their surrounding rural area as a result of anthropogenic modification of land surfaces, urban expansion, population growth, energy use, and its consequent generation of waste heat which causes alarming effects in many metropolitan areas (Lee, et al., September 2017).

Based on LST we can described UHI area of Palembang, like this figure:

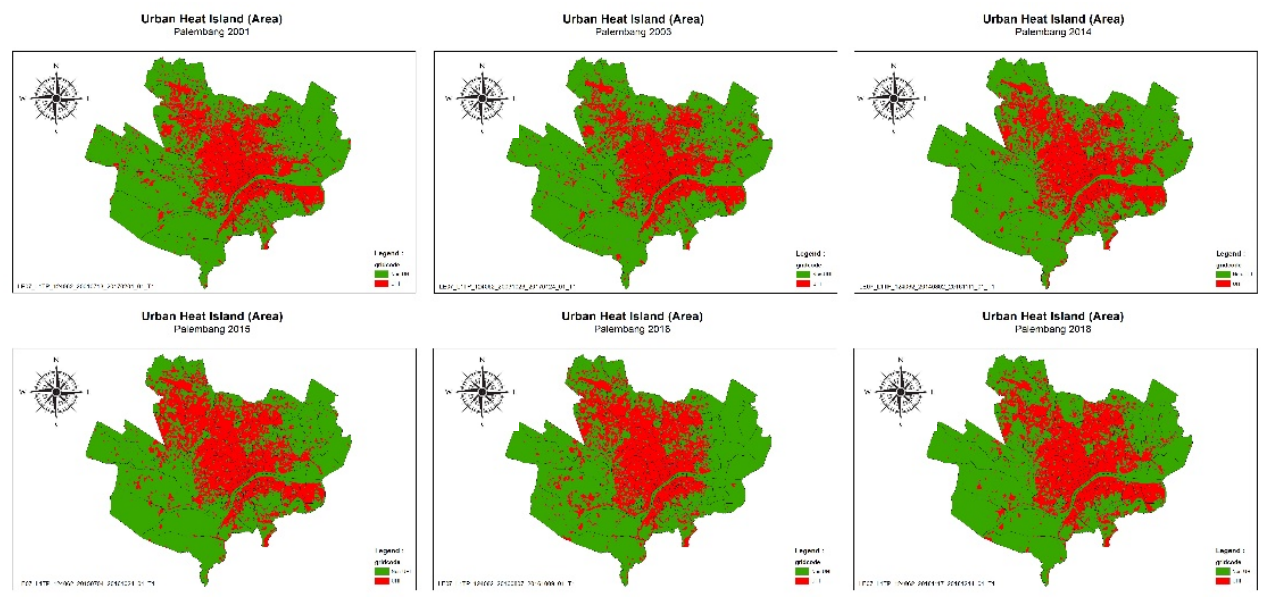

Fig. 5. UHI area of Palembang 
For detail area of UHI at Palembang, we can see in this table:

Table 6. UHI area of Palembang in $\mathrm{KM}^{2}$

\begin{tabular}{ccccccc}
\hline & \multicolumn{7}{c}{ UHI Area (Km2) } \\
\hline Years & 2001 & 2003 & 2014 & 2015 & 2016 & 2018 \\
\hline Non UHI & 260 & 264 & 256 & 242 & 249 & 247 \\
\hline UHI & 107 & 103 & 111 & 125 & 118 & 120 \\
\hline TOTAL & 367 & 367 & 367 & 367 & 367 & 367 \\
\hline
\end{tabular}

\subsection{Discussions}

\subsubsection{Correlation}

The correlation between Built-up and UHI can be describe in this chart:

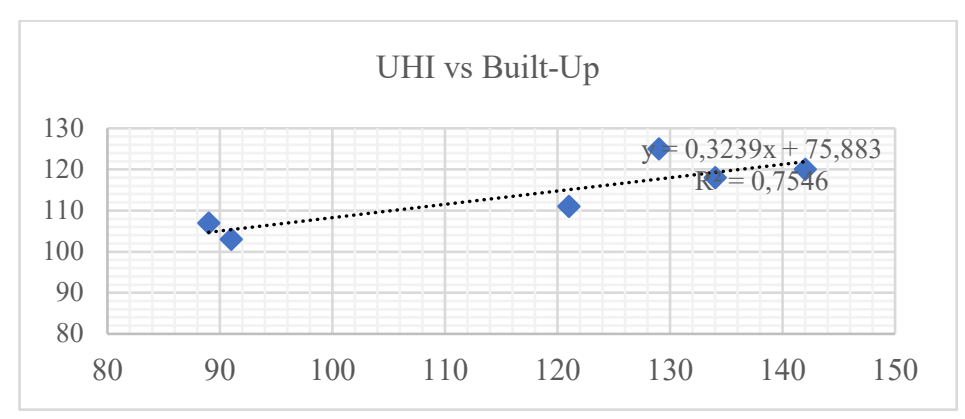

Fig. 6. Chart of correlation between built-up and UHI

This chart showed, there are positive correlation between UHI-BUI with R2 $=0.7546$

\subsubsection{Detail Correlation}

Based on this correlation, we can discuss more specific between Built-up and UHI. This part discusses about detail years and urban area. The area of built-up and UHI can showed like this:

Table 7. Comperation between UHI and Built-up area in $\mathrm{KM}^{2}$

\begin{tabular}{cccccccc}
\hline & $\mathbf{2 0 0 1}$ & $\mathbf{2 0 0 3}$ & $\mathbf{2 0 1 4}$ & $\mathbf{2 0 1 5}$ & $\mathbf{2 0 1 6}$ & $\mathbf{2 0 1 8}$ & TOTAL \\
\hline UHI & 107 & 103 & 111 & 125 & 118 & 120 & 684 \\
\hline BU & 89 & 91 & 121 & 129 & 134 & 142 & 706 \\
\hline
\end{tabular}


If Table showed in chart, can be showed like this:

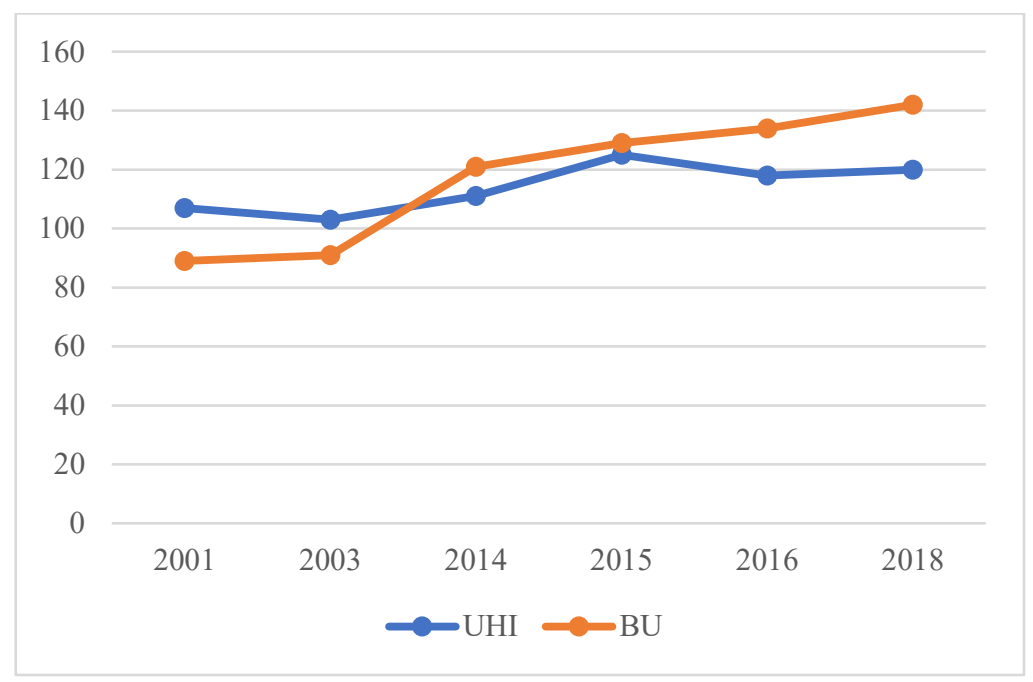

Fig. 7. Chart Correlation between UHI and Built-Up

In fig 7. showing that in 2014 and 2015 BU and UHI have an increased data compare previous year. After 2015, Built-up growth still continue, but in UHI has decreased. In this part, we focused at 2015 .

That area which have increase data in 2014 to 2015 located in north side of Palembang. There are four sub-district in north side of Palembang: sub-district Sako, sub-district Sematang Borang, sub-district Sukarami, and sub-district Alang-alang Lebar, This is the population growth of this north side of Palembang:

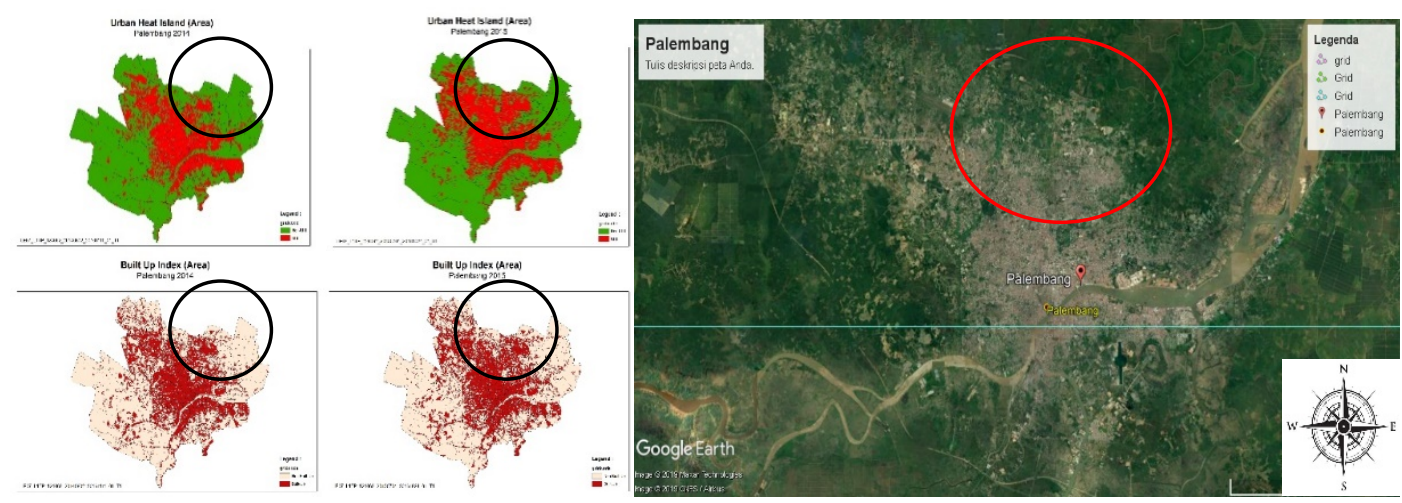

Fig. 8. Detail Analysis Growth Urban Area at 2014 and 2015 


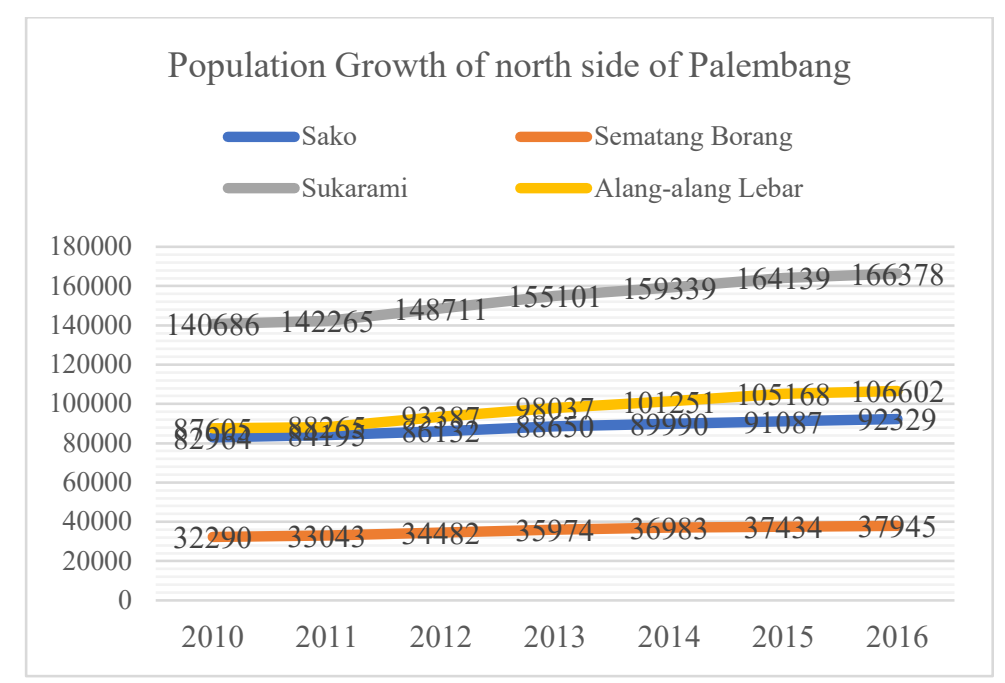

Fig. 9. Population growth of North side of Palembang ${ }^{4}$

In Fig 9, we can see that Sukarami sub-district is the greatest population in north side of Palembang. Sukarami sub-district is sub-urban area. This sub-district have an airport and also large residential area.

Back to main question, Was it urban growth of Palembang corelated with sport event? Palembang become the host of national sport event, PON XIV in 2004. Palembang also become co-host with Jakarta for sport event of South East Asia conturies, SEA Games XXVI, in 2011. After 2011, Palembang prepared to become co-host of Asian Games in 2018. Palembang build infrastucture for support that event in 2015. One of modern infrastucture is Light RailTransit (LRT) which started in end of 2015. This modern moda transportation started at airport and the end station in Jakabaring sport city in the south side of Palembang. From figure 8 in previous, we can see that Jakabaring sport city in north side didn't have increased data of UHI or BU, because this area already built in 2003, before PON XIV.

Sport event in Palembang have an indirect effect of Built Up and UHI. The urban growth of Palembang in the north side occured due the infrastructure construction, like road and LRT. Urban growth of Palembang was dominated by housing development. The housing development was driven by roads and modern transportation (LRT).

\subsubsection{Correction Image of Remote Sensing}

In validation step of the result of remote sensing data image, this research did not used data from maps at 2012 and 2014. This paper also did not do the advance correction like Pons and team did (Pons, Pesquer, Cristóbal, \& González-Guerrero, 2014).

\footnotetext{
${ }^{4}$ Source: https://palembangkota.bps.go.id/dynamictable/2015/12/07/24/jumlah-penduduk-kotapalembang-tahun-2010-2016.html
} 
Table 8. Result of Built-Up (in $\mathrm{KM}^{2}$ )

\begin{tabular}{ccccccccc}
\hline \multicolumn{8}{c}{ Area ( Km2 ) } \\
\hline & 2001 & 2003 & 2007 & 2012 & 2014 & 2015 & 2016 & 2018 \\
\hline Non BU & 278 & 276 & 190 & 190 & 246 & 238 & 233 & 225 \\
\hline BU & 89 & 91 & 177 & 177 & 121 & 129 & 134 & 142
\end{tabular}



Fig. 10. The Chart Of Buit-Up And UHI (In KM²)

The maps from 2007 and 2012 can be shown like this :

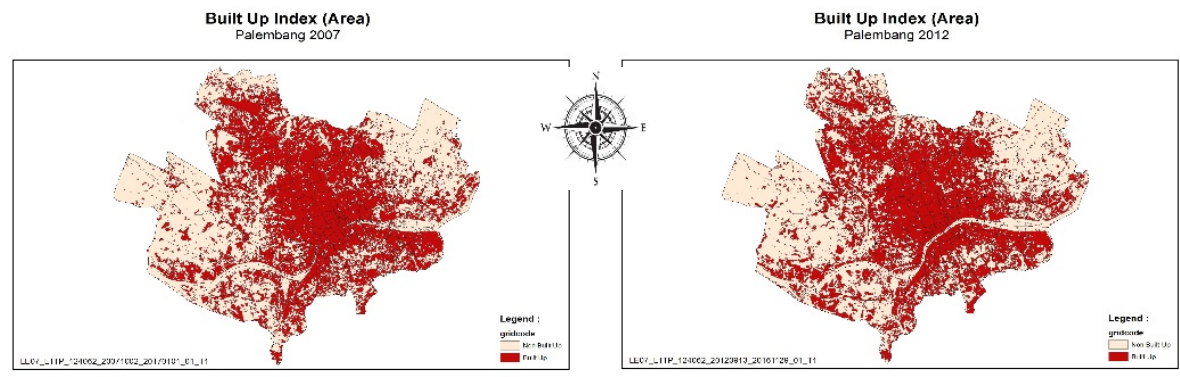

Fig. 11 Built-up Maps at 2007 and 2012

From data above shown that at 2007 and 2012 there is something 'wrong' in the Palembang image which capture from landsat 7. In map 2007 (fig 11), we can saw that Musi River become 'build up'area. This data must be cross check with weather data of Palembang 
in 2007. This research didn't did the cross check data analysis with weather data but did with Pearson corellation and Reliability Statistic with Cronbach's alpha method. This is the debility of the remote sensing, we must compare the ground data like a weather or cross check with the real data in the field.

\section{Conclusion}

This paper showed that remote sensing data analysis and GIS technique could measured the urban growth and environment impact, especially in temperature. The urban growth of Palembang driven by sport event indirectly. The infrastructure construction pushing the direction of urban growth. In Palembang case, the UHI phenomenon located in housing area in the north side of Palembang.

This paper also showed the weakness of this technique. Dataset in 2007 and 2012 was not valid to analysis. In this paper didn't analized more about the failness of that data. There are several potential problem which predispose to dataset. The anomali of climate or clearness of landsat image and several aspect can affect in validation of dataset.

Acknowledgements. We are a greatfull to Mr. Hery Setiawan Purnawali for a kindness discussion in methodology phase. We also thank you for a member of urban growth and sprawl groups: Mr. Fajri Romdhoni, Mr. Adam Fitriawijaya, Mr. Anta Sastika and Mr. Hendi Warlika Sedoputro. This paper can not be completed without a great discussion in this grup.

\section{References}

[1] Batty, M. (2013). Big data, smart cities and city planning. Dialogues in Human Geography, 3(3), 274-279. https://doi.org/10.1177/2043820613513390

[2] He, C., Shi, P., Xie, D., \& Zhao, Y. (2010). Improving the normalized difference built-up index to map urban built-up areas using a semiautomatic segmentation approach. Remote Sensing Letters, 1(4), 213-221. https://doi.org/10.1080/01431161.2010.481681

[3] Hidayati, I. N., Suharyadi, R., \& Danoedoro, P. (2018). Developing an Extraction Method of Urban Built-Up Area Based on Remote Sensing Imagery Transformation Index. Forum Geografi, 32(1). https://doi.org/10.23917/forgeo.v32i1.5907

[4] Jeevalakshmi, D., Narayana Reddy, S., \& Manikiam, B. (2017). Land surface temperature retrieval from LANDSAT data using emissivity estimation. International Journal of Applied Engineering Research, 12(20), 9679-9687.

[5] Pons, X., Pesquer, L., Cristóbal, J., \& González-Guerrero, O. (2014). Automatic and improved radiometric correction of landsat imageryusing reference values from MODIS surface reflectance images. International Journal of Applied Earth Observation and Geoinformation, 33(1), 243-254. https://doi.org/10.1016/j.jag.2014.06.002

[6] Santun, D. I. (2011). Vinesia dari Timur : memaknai Produksi dan Reproduksi Simbolik kota Palembang dari Kolonial sampai Pascakolonial. Yogyakarta: Ombak.

[7] Sevenhoven, J. (2015). Lukisan tentang Ibu Kota Palembang. Jakarta: Ombak.

[8] Zhang, Z., \& Du, Q. (2019). A Bayesian Kriging regression method to estimate airm temperature using remote sensing data. Remote Sensing, 11(7), 1-19. https://doi.org/10.3390/rs11070767 